\title{
Corrigendum to "Cost-competitiveness of organic photovoltaics for electricity self- consumption at residential buildings: A comparative study of Denmark and Greece under real market conditions" [Appl. Energy 208 (2017) 471-479]
}

Chatzisideris, Marios Dimos; Laurent, Alexis; Christoforidis, Georgios C.; Krebs, Frederik C

Published in:

Applied Energy

Link to article, DOI:

10.1016/j.apenergy.2018.03.019

Publication date:

2018

Document Version

Peer reviewed version

Link back to DTU Orbit

Citation (APA):

Chatzisideris, M. D., Laurent, A., Christoforidis, G. C., \& Krebs, F. C. (2018). Corrigendum to "Costcompetitiveness of organic photovoltaics for electricity self-consumption at residential buildings: A comparative study of Denmark and Greece under real market conditions" [Appl. Energy 208 (2017) 471-479]. Applied Energy, 219, 425. https://doi.org/10.1016/j.apenergy.2018.03.019

\section{General rights}

Copyright and moral rights for the publications made accessible in the public portal are retained by the authors and/or other copyright owners and it is a condition of accessing publications that users recognise and abide by the legal requirements associated with these rights.

- Users may download and print one copy of any publication from the public portal for the purpose of private study or research.

- You may not further distribute the material or use it for any profit-making activity or commercial gain

- You may freely distribute the URL identifying the publication in the public portal 


\title{
Corrigendum
}

Corrigendum to "Cost-competitiveness of organic photovoltaics for electricity self-consumption at residential buildings: A comparative study of Denmark and Greece under real market conditions" [Appl. Energy 208 (2017) 471-479; DOI: http://dx.doi.org/10.1016/j.apenergy.2017.10.003 ]

\author{
Marios D. Chatzisideris ${ }^{\mathrm{a},{ }^{* 1}}$, Alexis Laurent ${ }^{\mathrm{b}}$, Georgios C. Christoforidis ${ }^{\mathrm{c}}$, Frederik C. Krebs ${ }^{\mathrm{a}}$
}

${ }^{a}$ Department of Energy Conversion and Storage, Technical University of Denmark, Roskilde, Denmark

${ }^{\mathrm{b}}$ Division for Quantitative Sustainability Assessment, Department of Management Engineering, Technical University of Denmark, Lyngby, Denmark

${ }^{\mathrm{c}}$ Department of Electrical Engineering, Western Macedonia University of Applied Sciences, Kozani, Greece

The authors regret to admit the following typing errors:

1) There was a typing error in the denominator of the fraction in Equation (3) on page 474. Thus, Equation (3) on page 474 should read:

$$
N P V=\sum_{\text {year }=1}^{20} \frac{\text { bill savings }_{\text {year }}}{(1+\text { real } D R)^{\text {year }}}-O P V \text { system costs }
$$

2) The unit of the total PV/OPV systems costs should read "€/Wp" (i.e. euro per watt-peak) instead of "€/kWp" (i.e. euro per kilowatt-peak) in:

- paragraphs 2 and 3 on page 477,

- paragraph 1 on page 478,

- $\quad y$-axis in Figure 5 on page 478, as shown below.

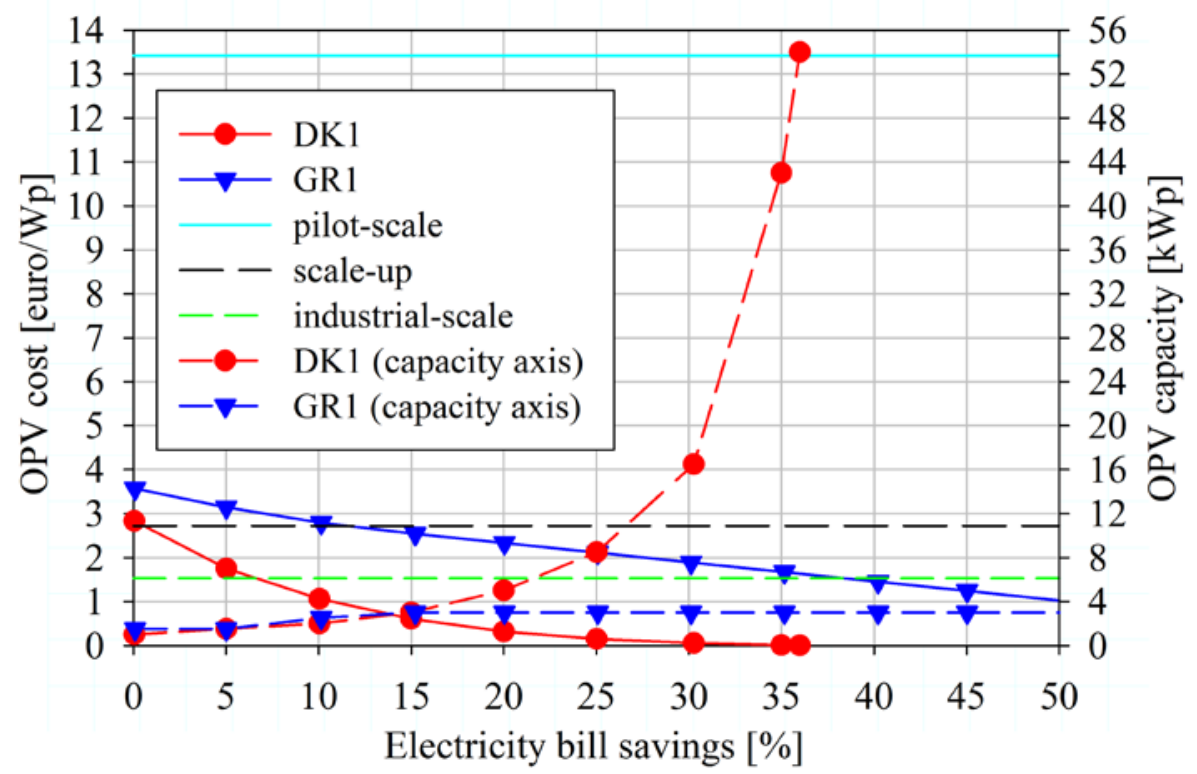

Figure 5. Total PV system costs for which a range of electricity bill savings could be achieved under current market conditions in Denmark (DK1) and Greece (GR1). The pilot-scale, scale-up and industrial-scale OPV cost levels are included for benchmarking.

The above typing errors do not reflect any calculations errors and do not compromise the findings of the paper. The authors would like to apologise for any inconvenience caused.

\footnotetext{
${ }^{1}$ Corresponding author at: Bygningstorvet Building 116B, 2800 Kgs. Lyngby, Denmark E-mail address: madc@dtu.dk (M.D. Chatzisideris)
} 